\title{
OPINION \\ Traditional male circumcision: Balancing cultural rights and the prevention of serious, avoidable harm
}

\section{K G Behrens}

Kevin Behrens is a senior lecturer in the Steve Biko Centre for Bioethics, School of Clinical Medicine, Faculty of Health Sciences, University of the Witwatersrand, Johannesburg, South Africa.

Corresponding author: K G Behrens (kevin.behrens@wits.ac.za)

The right to participate in cultural practices should be protected. However, it is a limited right, and does not entail a right to activities that cause serious and avoidable harms. I argue that the harms currently resulting from traditional circumcision are very serious, and that we have an obligation to ensure that the practice is effectively regulated so as to minimise them.

S Afr Med J 2014;104(1):15-16. DOI:10.7196/SAMJ.7493

Traditional male circumcision is regarded as a sacred and indispensable cultural rite intended to prepare initiates for the responsibilities of adulthood. ${ }^{[1]}$ Each year in South Africa (SA) thousands of youths enter initiation schools. Tragically, scores of these initiates experience medical complications and require treatment for, among other things, septicaemia, gangrene, severe dehydration and genital mutilation. Penile amputations and deaths also occur. ${ }^{[1,2]}$ With multiple deaths, hundreds of boys and young men requiring hospitalisation, and some having to undergo partial or total amputations, 2013 was a particularly bad year. ${ }^{[3]}$

The situation creates a moral dilemma: on the one hand, the right of people to participate in their cultural practices ought to be protected; on the other, initiates ought to be protected from harm. How do we balance these competing obligations? I argue that, all 
things considered, our obligation to prevent serious harm outweighs the rights of people to cultural practice. The right to traditional circumcision is limited, and should only be protected insofar as it does not result in serious harm. This does not imply that the practice should be abolished. Rather, the practice should be regulated and measures to prevent harm should be taken and enforced.

The SA Constitution establishes a right to 'participate in the cultural life of ... choice. ${ }^{\text {[4] }}$ The Children's Act (No. 38 of 2005) allows for the circumcision of males over 16 years of age, with consent and carried out in the prescribed manner. The intention of the law is to allow for traditional circumcision of boys over 16 who belong to groups in which the practice is customary. This represents a legal concession to particular cultural groups. Traditional circumcision is therefore lawful, but is it morally justified? Our Constitution establishes a right to cultural practice, but this is not uncontroversial. Are there good reasons to protect the right to cultural practice? I want to defend the claim that there are important social goods to be obtained by participation in one's culture, and that people should not be denied these social goods without good reason.

Recently, much attention has been given to cultural rights and to 'identity politics.' Taylor ${ }^{[5]}$ argues that 'authenticity' is a social good that should be protected and that our sense of identity grows out of belonging to a culture. In the face of the dominance of Western culture, it is necessary to protect the distinctiveness of other cultures so that they do not become 'assimilated to a dominant ... identity ... This assimilation is a cardinal sin against the ideal of authenticity.' Kymlicka ${ }^{[6]}$ similarly claims that our individual identity is rooted in our cultural identity. 'People's selfrespect is bound up with the esteem in which their national group is held. If a culture is not generally respected, then the dignity and self-respect of its members will also be threatened.' I broadly agree with these theorists. Cultural identity is important and our sense of self-worth is closely associated with a sense of belonging to a primary social group. We should therefore ensure that people are generally free to practise their culture.

In SA, we have particularly strong grounds for ensuring cultural rights, based on our historical experience of oppression. In the past, indigenous cultures were denigrated, suppressed and regarded as primitive. Steve $\mathrm{Biko}^{[7]}$ described an 'inferiority complex' experienced by black people who internalised the image of themselves portrayed by the oppressor: 'No longer was reference made to African culture, it became barbarism. Africa was the "dark continent". Religious practices and customs were ... superstition ... No wonder the African child learns to hate his heritage.' For Biko, the oppressed need to first reclaim their dignity and self- image before they can truly be free. The attack on indigenous cultures was an assault on the dignity and identity of many. Given this historical injustice, it is exceptionally important that people have their dignity restored by being able to practise their culture and embrace their identity. It is a matter of restorative justice that traditional cultures should be respected.

We ought to protect the right to cultural participation. But this right is conditional and not absolute. Surely where serious and avoidable harm results from the exercise of any right, society has justified grounds for limiting the exercise of that right? Surely the right to culture should be limited to practices that do not cause significant harm? So, the question is: what is the extent and nature of the harms caused by traditional circumcision? If these harms are insignificant, the practice should be allowed to continue just as it is. Unfortunately, this is not so: traditional circumcisions are currently the cause of significant harm to many initiates. I want to defend this claim briefly.

According to Kepe, ${ }^{[2]}$ from 1995 to 2005 in the Eastern Cape alone, 5813 hospital admissions, 281 penile amputations and 342 deaths were reported. This is an annual average of 528.5 admissions, 25.5 amputations and 31 deaths. Since these statistics apply only to one province, this is a serious public health concern. The number of deaths is very worrying, but so is the number of amputations. In addition, badly performed and badly managed circumcisions can result in serious infections and in scarring and mutilation of the genitals, with many non-trivial implications, including severe pain. There are also concerns regarding potential transmission of infections when traditional practitioners fail to use sterilised instruments. ${ }^{[2]}$ There are a number of factors that contribute to the harm caused. Traditional practitioners are often insufficiently trained to perform these surgeries. Poor postoperative management, binding the wound too tightly, and traditional restrictions on drinking water all lead to complications. Social pressure to complete the initiation without outside medical intervention often results in initiates seeking medical help too late. Initiates may also be the victims of violence. The custom that requires secrecy and restricts contact to other circumcised men makes oversight of the process by medical personnel nearly impossible.

What makes these harms even more ethically serious is that they are generally avoidable. It is not circumcisions themselves that place initiates in danger, it is how they are done. The avoidable deaths, penile amputations, genital mutilations, and other health threats are very serious harms, and the right of initiates not to be harmed in these ways surely outweighs the right to cultural practice. This is not only intuitively obvious - ethically it is supported in our law. As with many other rights, the right to practise culture is guaranteed only insofar as it is not exercised in a 'manner inconsistent with any [other] provision of the Bill of Rights'. ${ }^{[4]}$ There are also rights to human dignity, freedom and security of the person, and to life, all of which are being denied to some initiates.

While traditional circumcision, as currently practised, causes serious harm, prohibiting this practice is not the only way to prevent harm. With effective regulation and management, the social good of protecting cultural practice can be achieved at the same time as ensuring that harm to participants is minimised.

As Kepe ${ }^{[2]}$ points out, the "health crisis in ritual male circumcision $\ldots$ is in fact a government responsibility. Therefore, in addition to its constitutional obligation to protect the health of the people, the government may want to be seen as taking this issue seriously. ${ }^{[2]}$ So far, attempts to regulate these circumcisions have had limited success. Greater political will, effective monitoring, and prosecution and punishment of offenders are required. Traditional leaders also bear much responsibility and need to be aware that their right to perform traditional surgeries is a privilege granted by society to show respect for culture. The right to keep that privilege may require that some of the customary aspects of the practice need to change, to prevent harm. It has been reported that the Congress of Traditional Leaders of South Africa has called for co-operation between the National Department of Health and itself. ${ }^{[8]}$ This is very welcome news. However, the need for action is urgent. It is surely possible to find a way to protect culture and ensure the health and well-being of initiates.

\footnotetext{
Ntombana L. Should Xhosa male initiation be abolished? International Journal of Cultural Studies 2011;14(6):631-640. [http://dx.doi.org/10.1177/1367877911405755]

(1) Kepe T. Secrets that kill: Crisis, custodianship and responsibility in ritual male circumcision in the eastern Cape Prove Makurdi W. Botched circumcision from initiation rituals fill S. African hospital. The Seattle Times, August 2013. http://seattletimes.com/html/nationworld/2021579230_initiationdeathsxml.html (accessed 26 August 2013).

4. South African National Government. Constitution of the Republic of South Africa, Chapter 2. Pretoria Government Printer, 1996. http://www.info.gov.za/documents/constitution/1996/96cons2.htm (accessed 1 September 2013).

Taylor C. Multiculturalism: Examining the politics of recognition. In: Gutman A, ed. Multiculturalism: Examining the Politics of Difference. Princeton: Princeton University Press, 1994

6. Kymlicka W. The Rights of Minority Cultures. New York: Oxford University Press, 1995.

7. Biko S. I Write What I Like. Johannesburg: Picador Africa, 2004.

8. Bateman, B.Contralesatoaddressinitiation deaths. Eyewitness News, 2 August2013.http://www.google.co.zz/ url? $\mathrm{sa}=t \& \mathrm{rct}=j \& \mathrm{q}=\& \mathrm{esrc}=\mathrm{s} \& \mathrm{frm}=1 \&$ source $=$ web $\& \mathrm{~cd}=1 \& \mathrm{ved}=0 \mathrm{CCkOFjAA} \& \mathrm{rurl}=\mathrm{http} \% 3 \mathrm{~A} \% 2 \mathrm{~F} \% 2 \mathrm{Fewn}$ urlsa-tQrel-j\&q=Qesc=s\&2 co.za $2013 \% 2 \mathrm{~F}$. September 2013).
} 